Mohammed Al-Nasarat (Ma’an)

\title{
From Paganism to Christianity. General Remarks on the Religious Changes in Petra $\left(1^{\text {st }}-6^{\text {Th }}\right.$ Cent. AD)
}

\section{Introduction}

The $1^{\text {st }}$ century AD, Greek historian Strabo mentions that the Nabataeans 1 are a sensible people, and are so much inclined to acquire possessions that they publicly fine anyone who has diminished [them], and also confer honors on anyone who has increased them... ${ }^{1}$ Strabo also points out that they worship the sun, building an altar on the top of the house, and pouring libations on it daily and burning frankincense $^{2}$. John F. Healey mentions that Dushara ${ }^{3}$ represents the sun among the Nabataeans $s^{4}$. Some scholars think that Dushara was worshipped in Petra beginning in the $4^{\text {th }}$ century $\mathrm{BC}$ - the time when the Nabataeans settled down in the area, which was under the occupation of the Edomites ${ }^{5}$. The Nabataeans worshipped the same deities that they used to venerate in their original homeland in the Arabian Peninsula'; these included Allat, el-'Uzza, Manat, Dushara, and Shai al-Qaum, the god who hates drinking wine and protects the tribe ${ }^{7}$. These were gods that the Nabataeans brought with themselves around the $4^{\text {th }}$ century $\mathrm{BC}^{8}$. Thus, like other Arabs from the Arabian Peninsula, the Nabataeans worshipped

\footnotetext{
${ }^{1}$ Strabo, Geography, XVI, 4, 26, trans. H.L. Jones, London 1932 [= LCL, 49] (cetera: Strabo).

${ }^{2}$ Strabo, XVI, 4, 26.

${ }^{3}$ Dushara means the one of the Shara mountain range. Thus, it seems that the name Al-Shara is connected with a geographical area. J.F. Healey, The Religion of the Nabataeans. A Conspectus, Leiden 2001 [= RGRW, 136], p. 23. M. Murray, Religion and the Nomadic Lifestyle. The Nabateans, [in:] Travel and Religion in Antiquity, ed. P.A. Harland, Waterloo Ontario 2001 [= SCJ, 21], p. 230. ${ }^{4}$ J.F. Healey, The Religion..., p. 103.

${ }^{5}$ R. Wenning, North Arabian Deities and the Deities of Petra. An Approach to the Origins of the Nabataeans, [in:] Men on the Rock. The Formation of Nabataean Petra, ed. S.G. Schmid, M. Mouton, Berlin 2013, p. 339. F. Zayadine, The Nabataean Gods and Their Sanctuaries, [in:] Petra Rediscovered. Lost City of the Nabataeans, ed. G. MarkoE, New York 2003, p. 58.

${ }^{6}$ F. Zayadine, The Nabataean..., p. 58.

${ }^{7}$ J. Teixidor, The Pagan God. Popular Religion in the Greco-Roman Near East, Princeton 1977, p. 70; J.F. Healey, The Religion..., p. 103; P. Alpass, The Religious Life of Nabataea, Leiden-Boston 2013 [= RGRW, 175], p. 278.

${ }^{8}$ Z. Al-Salameen, Introduction to History and Civilization of Petra, Amman 2010, p. 165.
} 
the god Dushara, who was considered the greatest Nabataean god ${ }^{9}$. The Nabataeans engaged in building temples ${ }^{10}$, designed as places of worship. These temples were spread all over the regions of the Nabataean Kingdom and included objects such as the Temple of Winged Lions ${ }^{11}$, the Great Temple ${ }^{12}$, and the Temple of Qasr el-Bint in Petra, considered the most famous temple in the city; it was specially meant for the worship of Dushara ${ }^{13}$.

Any discussion on the earliest relationships between Christianity and the region of Petra should take into account two Pauline epistles. The first one - Galatians - mentions Paul's journey to Arabia after he became a follower of Jesus Christ, and then his return to Damascus. Thus, he writes in his letter to the Galatians: but I went into Arabia and returned again unto Damascus (Gal 1, 15-17).

In his epistle to the Galatians and their churches, beside preaching and discussing matters of faith, Saint Paul talks about his trip from Jerusalem to Damascus and then his return to Arabia (the Kingdom of the Nabataeans) conducted at the Lord's behest, after he was oppressed by the Jews in Jerusalem ${ }^{14}$. Some scholars maintain that Paul's epistle was written during the period of $40-50 \mathrm{AD}^{15}$, and that during his missionary activity the term 'Arabia' referred to the Nabataean Kingdom, extending from Damascus in the north to Made'n Saleh in the south and ruled by king Aretas IV (9 BC-40 AD $)^{16}$; the latter was connected by affinity with the family of the Jewish king Herod ${ }^{17}$. Paul does not mention in his letter how far he traveled into the Nabataean Kingdom or how much time he spent there; it seems, however, that he carried out his missionary activities and preaching among the Nabataeans and the citizens of Damascus. Some scholars mention that Paul settled among the Nabataeans for at least two to three years after he had converted to Christianity, and that he spent that time in contemplation and prayer - the more so because when he was in Damascus, he was passing through a time

\footnotetext{
${ }^{9}$ J.F. Healey, The Religion..., p. 97; F. Zayadine, S. Farajat, Excavation and Clearance at Petra and Beida, ADAJ 35, 1991, p. 282.

${ }^{10} \mathrm{~A}$. Negev argues that most of the Nabataean temples were built during the reign of king Obadas III (9/8 BC-40 AD), cf. A. Negev, The Chronology of the Middle Nabatean Period, PEQ 101, 1969, p. 13.

${ }^{11}$ P.C. Hammond, The Temple of the Winged Lions, [in:] Petra Rediscovered..., p. 223-229.

${ }^{12}$ M. Joukowsky, The Great Temple, [in:] Petra Rediscovered..., p. 214-223.

${ }^{13}$ F. Zayadine, Recent Excavations and Restoration at Qasr el Bint of Petra, ADAJ 29, 1985, p. 239-249; J.F. Healey, The Religion..., p. 39.

${ }^{14}$ R.A. BAILeY, The Structure of Paul's Letters, p. 55, www.inthebeginning.org/structure/complete.pdf [8 X 2018].

${ }^{15}$ B. Macdonald, What Happened to the Nabataeans? The Literary and Archaeological Evidence, [in:] Studies on the Nabataean Culture II. Refereed Bulletin of the International Conference on the Nabataean Culture, ed. N.I. Khairy et al., Amman 2016, p. 186.

${ }^{16}$ R. Smith, Arabia, [in:] The Anchor Bible Dictionary, vol. I, ed. D. Freedman, New York-London 1992, p. 326.

${ }^{17}$ B. Macdonald, What Happened..., p. 187.
} 
of confusion and bewilderment. Thus, the trip to the Nabataean Kingdom would have given him more time for contemplation, allowing him to reorganize his apostolic ideas and to prepare for the great mission he was entrusted with ${ }^{18}$.

In the other letter - 2 Corinthians - we read: In Damascus the governor under Aretas the king kept the city of the Damascenes with a garrison, desirous to apprehend me: and through a window in a basket was I let down by the wall and escaped his hands (1 Cor 11, 32-33). The call of Apostle Paul did not lead to the rise of any Christian communities; there is no indication that there was a Christian presence among the Nabataeans during the period of Paul's visits to Damascus and the Nabataean Kingdom ${ }^{19}$. It appears from the letter sent to the Corinthian Christians that he was able to flee from the soldiers of Nabataean king Aretas IV stationed in Damascus (Act 9, 23-25). It seems that towards the end of his reign, king Aretas IV discovered the missionary activity of Paul in his kingdom, and thus he ordered his governor in Damascus to have him killed. This means that Paul's mission among the Nabataeans had not been particularly successful with regard to the propagation of Christianity; some scholars point out that the religion was entering the Nabataean kingdom at a slow pace ${ }^{20}$.

\section{From paganism to Christianity in Petra}

\section{Testimonies of narrative sources}

The adoption of Christianity as the religion of the Byzantine Empire had a profound influence on the culture of the region (which had lived under paganism for centuries), as evidenced by the number of churches built during the transition from paganism to Christianity. The conversion from paganism to Christianity in Petra is one of the most difficult periods to study, since there is no pertinent historical material. As mentioned above, in Petra the process of conversion to Christianity was slow ${ }^{21}$, especially bearing in mind the penetration of the pagan beliefs into the minds and culture of the local population. This is also reflected in the course of the transition from paganism to Christianity in the Byzantine Empire in general. The Byzantine Empire considered carefully to allow Christians to assimilate with the pagan society ${ }^{22}$. Paganism was an essential force in the Byzantine society

${ }^{18}$ C.W. Briggs, The Apostle Paul in Arabia, BWo 41, 1913, p. 255; M. Hengel, Paul in Arabia, BBR 12, 2002, p. 47.

${ }^{19}$ B. Macdonald, What Happened..., p. 187.

${ }^{20}$ K. Schmitt-Korte, An Early Christian Record of the Nabataeans. The Maslam Inscription (ca. 350 AD), ARAM.P 2, 1990, p. 123-142.

${ }^{21}$ Ibidem, p. 132.

${ }^{22}$ H. SARAdi, The Christianization of Pagan Temples in the Greek Hagiographical Texts, [in:] From Temple to Church. Destruction and Renewal of Local Cultic Topography in Late Antiquity, ed. J. HAHN, S. EmmeL, U. Gotter, Leiden 2008 [= RGRW, 163], p. 113-134. 
and therefore pagans were allowed to coexist with Christians at the beginning of the transition to maintain social unity within the state ${ }^{23}$.

Thus, paganism was found in Petra side by side with Christianity during the $4^{\text {th }}$ century $\mathrm{AD}$ and this state continued until the $5^{\text {th }}$ century $\mathrm{AD}^{24}$. It should be noted that Christianity did not spread throughout the Byzantine Empire in one blow; rather, it took a considerable period of time for it to become the official religion, and the use of certain pagan symbols in art and mosaics continued well into the Christian period. Bert de Vries mentions that the end of paganism in the regions of Jordan and southern Syria cannot be attributed to the coming of Christianity, but to the oppressive policy applied by the Byzantine state against the followers of the respective pagan cults, and the ensuing destruction of the cultural and religious identity of the pagans ${ }^{25}$. Helen Saradi states that the attitude of the Byzantine Empire towards paganism and its characteristics was linked firstly with the religious policy of the Byzantine emperors and secondly with the social and cultural reality of the empire's population during the $4^{\text {th }}$ and $5^{\text {th }}$ centuries $\mathrm{AD}^{26}$.

The Byzantine period of 324-636 AD was one of the most important timespans of intensive human settlement in the region ${ }^{27}$. During this time, Petra enjoyed immense importance as it became the capital of Palaestina Salutaris (Palaestina Tertia), which included southern Jordan in addition to the Negev and the Sinai ${ }^{28}$. Eusebius describes Petra during this period as 'the famous noble city ${ }^{29}$. He also discusses the construction of churches in the area in the period 324-337 AD, characterizing the city as full of superstitions and works of demons ${ }^{30}$. During the $4^{\text {th }}$ century AD, Petra was quite like any other Byzantine city in this respect: followers of ancient paganism and Christianity coexisted side by side, with the city torn by internal conflicts over whether to preserve and continue the use of old

${ }^{23}$ H. Saradi-Mendelovici, Christian Attitudes toward Pagan Monuments in Late Antiquity and Their Legacy in Later Byzantine Centuries, DOP 44, 1990, p. 47-61.

${ }^{24}$ Z. FiemA, Late-Antique Petra and Its Hinterland. Recent Research and New Interpretations, [in:] The Roman and Byzantine Near East, vol. III, ed. N. Humphrey, Portsmouth 2002 [= JRA.SS, 31], p. 194. ${ }^{25}$ B. DE VRIES, Between the Cults of Syria and Arabia. Traces of Pagan Religion at Umm al-Jimal, SHAJ 10, 2009, p. 190.

${ }^{26}$ H. Saradi-Mendelovici, Christian Attitudes..., p. 48.

${ }^{27}$ Z. Fiema, Economics, Administration and Demography of Late Roman and Byzantine Southern Transjordan (unpublished doctoral dissertation, University of Utah, 1991), p. 137; Z. FIEMA, The Islamic Conquest of Southern Jordan. A New Research Perspective, ADAJ 36, 1992, p. 329.

${ }^{28}$ Z. Fiema, Economics, Administration..., p. 23-39; W.D. WARd, From Provincia Arabia to Palaestina Tertia. The Impact of Geography, Economy, and Religion on Sedentary and Nomadic Communities in the Later Roman Province of Third Palestine (unpublished doctoral dissertation, University of California, 2008), p. 68-77.

${ }^{29}$ Eusebius' Life of Constantine, XXXVI, 13-14, trans. et ed. A. Cameron, S. Hall, Oxford 1999 [= CAHS] (cetera: EusEBIUs).

${ }^{30}$ Eusebius, XXXVI, 13-14. 
temples or to build churches. It seems that the enduring paganism and its celebration in Petra - with the concomitant presence of a Christian sect - led to inter-communal disputes ${ }^{31}$, which can be seen in the Byzantine historical sources.

When the Byzantine Empire converted to Christianity, the Nabataeans gradually followed suit, although the available ecclesiastical sources do not mention any bishops from Petra participating in the Council of Nicaea in $325 \mathrm{AD}^{32}$. This may be indicative of a religious dispute during the initial stages of Christianity in Petra: the religious division concerning the new religion and its nature sustained among its followers in Petra. While some of the city's priests attended the Orthodox councils, others followed the Arian doctrine of the human nature of Christ ${ }^{33}$. In 343 $\mathrm{AD}$, the Council of Sardica convened to discuss the Christian dispute over the nature of Christ. Church historian Theodoret (393-458 AD) states that the bishop of Petra, Asterius, rejected the ideas put forward by the followers of Arius and joined the other side of the conflict. Theodoret states that Asterius withdrew from the proceedings of the Ecumenical Council in Sardica and was subsequently banished to Libya by emperor Constantius $\mathrm{II}^{34}$. During the period 343-361 AD, a new bishop was appointed in Asterius's place. Epiphanius, bishop of Salamis in Cyprus, mentions the participation of Germanus, bishop of Petra, in the 359 AD Council of Seleucia, where the heresy of Arius of Alexandria was discussed ${ }^{35}$.

It seems that Germanus was appointed as bishop of Petra after the exile of bishop Asterius. However, in $362 \mathrm{AD}$ - during the reign of the pagan emperor Julian (361-364 AD) - Germanus was removed from his post, while Asterius was reappointed as the city's bishop and attended the Orthodox Council in Alexandria in $362 \mathrm{AD}^{36}$. It appears that the deposition of Germanus happened after Julian took over the rule in $361 \mathrm{AD}$. Indeed, in $362 \mathrm{AD}$, Christianity suffered a violent blow at the hands of emperor Julian, who declared his apostasy from Christianity - starting to persecute the religion anew - and returned to paganism ${ }^{37}$. This prompted the Christians to convene the Council of Alexandria in the same year at the invitation of pope Athenasuis. Most of the bishops who attended this Council returned from exile or had been tortured, including Asterius, bishop of Petra ${ }^{38}$.

${ }^{31}$ Z. Fiema, Reinventing the Sacred. From Shrine to Monastery at Jabal Hārūn, PSAS 42, 2012, p. 27-38.

${ }^{32}$ A. Harnack, The Mission and Expansion of Christianity in the First Three Centuries, vol. II, trans. et ed. J. Moffatt, New York 1908, p. 2, 117.

${ }^{33}$ B. Macdonald, What Happened..., p. 190.

${ }^{34}$ Theodoret, Kirchengeschichte, VI, 8, ed. L. Parmentier, Berlin 1954 [= GCS, 44].

${ }^{35}$ The Panarion of Epiphanius of Salamis. Books II and III, De fide, 115, 26, 8, trans. F. Williams, ${ }^{2}$ Leiden-Boston 2013 [= NHMS, 79] (cetera: Epiphanius, The Panarion).

${ }^{36}$ T.D. Barnes, Athanasius and Constantius. Theology and Politics in the Constantinian Empire, Cambridge Massachusett 2001, p. 236-264.

${ }^{37}$ Sozomenus, Church History from AD 323-425, VI, 3, trans. C.D. Hartranft, [in:] NPFC II, vol. II, ed. P. Schaff, H. WACE, New York 1890 (cetera: Sozomenus).

${ }^{38}$ Z. FiEmA, Reinventing the Sacred..., p. 32. 
There is no information on the relationship between the two bishops of Petra, Asterius and Germanus, during this period.

Despite the damage that Petra was exposed to in the earthquake of $363 \mathrm{AD}$, and the destruction of parts of the city, it continued to be a vibrant center, becoming the seat of a Byzantine bishopric ${ }^{39}$. An example of a Christian presence in Petra in the mid- $4^{\text {th }}$ century $\mathrm{AD}$ - specifically, the presence of influential bishops during this period - is the account concerning monk Paul of Petra, who was the head of the Raithu monastery in Mount Sinai. The monastery and the monks residing there were exposed to a massacre at the hands of the Saracens, who attacked the monastery in the years $373-378 \mathrm{AD}^{40}$.

However, it would be difficult to conclude that paganism was completely eradicated from the areas under the rule of the Nabataeans. A slow transition to the Christian religion was underway, with the Nabataeans continuing to worship their gods even during the Christian period ${ }^{41}$. Some researchers point out that the process of transition to Christianity in Petra was particularly slow, sometimes proceeding at an uneven pace ${ }^{42}$. Thus, pagan worship continued in Petra alongside the construction of new churches. Christian historian Eusebius speaks about the construction of churches in Petra as well as the existence of paganism during this period $^{43}$. This means that the city saw dual pagan and Christian worship in the first third of the $4^{\text {th }}$ century AD. Similarly, Church historian Sozomen (370-450 $\mathrm{AD})$ mentions that Areopolis and Petra were among the cities whose pagan people defended their temples, and says:

There were still pagans in many cities, who contended zealously in behalf of their temples; as, for instance, the inhabitants of Petræa and of Areopolis, in Arabia; of Raphi and Gaza, in Palestine ${ }^{44}$.

Sozomen's wording indicates that paganism persisted in Petra until the end of the $4^{\text {th }}$ century $\mathrm{AD}$, and probably the beginning of the $5^{\text {th }}$. This means that the transition from paganism to Christianity passed through harsh and difficult conditions during the $4^{\text {th }}$ and $5^{\text {th }}$ centuries AD. Sozomen links the destruction of the temples in the city of Petra with the closure of the temple of Serapeum in Alexandria, which strengthened the triumph of Christianity over paganism ${ }^{45}$. These

\footnotetext{
${ }^{39}$ M. Joukowsкy, The Great Temple..., p. 32; Z. Fiema, From the Annexation to Aaron. Petra in Roman and Byzantine Times, [in:] Petra. A City Forgotten and Rediscovered, ed. J. Frösen, Z. FIEmA, Helsinki 2002, p. 67.

${ }^{40}$ I. SHAHID, Byzantium and the Arabs in the Fourth Century, Washington 1984, p. 298.

${ }^{41}$ J.F. Healey, The Religion..., p. 16.

${ }^{42}$ Z. Fiema, The Byzantine Church at Petra, [in:] Petra Rediscovered..., p. 239-249; W. Tabbernee, Early Christianity in Contexts. An Exploration across Cultures and Continents, Grand Rapids 2014, p. 58.

${ }^{43}$ Das Onomastikon der biblischen Ortsnamen, XXXVI, 13-14, ed. E. Klostermann, Hildesheim 1966.

${ }^{44}$ Sozomenus, VII, 15, 11-12.

${ }^{45}$ Sozomenus, VII, 15, 11-12.
} 
events are dated to $391 \mathrm{AD}$, a period of mutual hostility between the pagans and Christians in the region in general ${ }^{46}$.

The closure of the temples was a consequence of the legislation issued by emperor Theodosius I prohibiting the practice of pagan rituals in the empire. Importantly, Sozomen's words indicate that there was still a pagan sect in Petra as late as at the beginning of the $5^{\text {th }}$ century AD.

The spread of Christianity in Petra did not prevent the persistence of pagan worship until the end of the $4^{\text {th }}$ century AD. In his most famous work - the Panarion - Epiphanius (315-403 AD) describes the worship of Dushara and the celebrations held in Petra as well as in some nearby areas (such as Khulsa in the Negev) on the $25^{\text {th }}$ of December of each year. He writes:

First, at Alexandria, in the Coreum, as they call it; it is a very large temple, the shrine of Core. They stay up all night singing hymns to the idol with a flute accompaniment. And when they have concluded their nightlong vigil torchbearers descend into an underground shrine after cockcrow [...] This also goes on in the city of Petra, in the idolatrous temple there. (Petra is the capital city of Arabia, the scriptural Edom). They praise the virgin with hymns in the Arab language and call her Chaamu - that is, Core, or virgin - in Arabic. And the child who is born of her they call Dusares, that is, 'the Lord's only-begotten'. And this is also done that night in the city of Elusa, as it there in Petra, and in Alexandria ${ }^{47}$

It is clear from Epiphanius's description of the persistent paganism and continued worship of the god Dushara until the end of the $4^{\text {th }}$ century AD - and the performing of the rituals of worship in the Nabataean language - that the Nabataeans represented this god in a solid form. This is in contrast to the forms of the gods that they had worshipped during the previous period, as a result of the influence of the Roman culture ${ }^{48}$; thus, this Dushara became Dusares, equated with Dionysus in the $5^{\text {th }}$ century $\mathrm{AD}^{49}$. Epiphanius considers these religious practices of the Nabataeans a kind of heresy ${ }^{50}$.

Epiphanius's description of the Nabataeans' celebration of Dushara might be associated with Strabo's 1st century AD description of the Nabataeans holding a feast, where the celebrating group along with the king drank wine from golden cups $^{51}$. According to J.F. Healey, Allat is the mother of the god Dushara; this would

\footnotetext{
${ }^{46}$ R. BAyLIss, Usurping the Urban Image. The Experience of Ritual Topography in Late Antique Cities of the Near East, [in:] TRAC 98. Proceedings of the Eighth Annual Theoretical Roman Archaeology Conference, Leicester 1998, ed. P. Baker, C. Forcey, S. Jundi, R. Witcher, Oxford 1999, p. 71.

${ }^{47}$ Epiphanius, The Panarion, 51, 22, 11.

${ }^{48}$ W.D. WARD, The 363 Earthquake and the End of Public Paganism in the Southern Transjordan, JLA 9, 2016, p. 154.

${ }^{49}$ K.D. Politis, Nabataean Cultural Continuity into the Byzantine Period, [in:] The World of the Nabataeans. Volume 2 of the International Conference The World of the Herods and the Nabataeans held at the British Museum, 17-19 April 2001, ed. IDEM, London 2007, p. 189.

${ }^{50}$ W.D. WARD, From Provincia..., p. 227.

${ }^{51}$ Strabo, XVI, 4, 26.
} 
be in line with the Nabataean inscription found in the region of Hawran in southern Syria, where it is mentioned that Allat is known as the 'mother of the gods' ${ }^{\text {' }}$. The continuation of Dushara's worship in Petra at the end of the $4^{\text {th }}$ century shows the integration of paganism and Christianity in Petra.

In the $5^{\text {th }}$ century $\mathrm{AD}$, Byzantine author Hesychius of Alexandria states that Dusares is Dionysus of the Nabataeans ${ }^{53}$. Certain $6^{\text {th }}$ century sources also mention that there were some stones that represented the gods in various areas close to Petra which were part of the Nabataean Kingdom and later entered the province of Palaestina Salutaris. Antoninus of Placentinus remarks at the end of the $6^{\text {th }}$ century that he saw some pagan practices by the Saracens in Mount Sinai ${ }^{54}$; the pagans erected an idol on Mount Sinai and directed their worship to it. The religious celebration by these Saracens was based on the waxing and the waning of the moon ${ }^{55}$. The persistence of paganism was not limited to the city of Petra; evidence of paganism may be seen in various parts of Palestine during the $4^{\text {th }}$ and $5^{\text {th }}$ centuries $\mathrm{AD}$ and continues at least until the $6^{\text {th }}$ century $\mathrm{AD}^{56}$.

The late Byzantine lexicon known as the Suda (dated to the $10^{\text {th }}$ century AD) mentions the worship of the god Dushara in Petra, stating:

\footnotetext{
'Theus Ares' [Dusares]: That is the god Ares, in Petra of Arabia. The god Ares is worshipped among them: for they honour him especially. The image is a black stone, square in shape, unshaped, four feet tall and two wide: it is mounted on a base of beaten gold. To this they sacrifice and pour the blood of the sacrificial animals, and that is how they make libations. And the whole house is rich in gold, and there are many votive offerings. ${ }^{57}$
}

Here, it must be said that the betyls found in different parts of the Nabataean kingdom and Petra in particular are similar to those mentioned in the text of the Suda in terms of form and size. Fawzi Zayadine remarks that rituals related to the worship of Dushara as described in the Byzantine lexicon were held in the Temple of Qasr el-Bint, and that the remnants of the golden foliage found in the temple confirms this; we read that the whole temple is shining with gold ${ }^{58}$.

Regardless of the spread of Christianity in Petra during the $4^{\text {th }}$ century and beyond, the evidence for Christian hostility towards the pagan forms of worship in Petra is uncertain, despite Sozomen's allusion to the pagans defending their temples during the $4^{\text {th }}$ century $\mathrm{AD}$. The archaeological material provides us with important information about the continued presence of the god Dushara in Petra during the later periods of the history of the city; a large bust of this god was found

\footnotetext{
${ }^{52}$ P. Alpass, The Religious..., p. 49.

${ }^{53}$ F. Zayadine, The Nabataean..., p. 60.

${ }^{54}$ U. Avner, Nabataean Standing Stones and Their Interpretation, ARAM.P 11-12, 1999-2000, p. 99.

${ }^{55}$ W.D. WARD, From Provincia..., p. 259.

${ }^{56}$ D. BAR, The Christianisation of Rural Palestine during Late Antiquity, JEH 54, 2003, p. 405.

${ }^{57}$ P. Alpass, The Religious..., p. 53.

${ }^{58}$ F. Zayadine, Recent Excavations..., p. 240.
} 
at the gate of the temple of Qasr al-Bint. The statue was found above a layer of sand that helped maintain it. Judith McKenzie believes that the statue remained in its original place at the gate of Qasr al-Bint throughout the Nabataean, Roman and Byzantine periods. This means that it survived the movement of iconoclasm that spread in Petra ${ }^{59}$, although this was a conflict that involved the followers of both paganism and Christianity. The Nabataean inscriptions found in the Oboda region of the Negev indicate that the Nabataeans in the region still worshiped Dushara during the early Byzantine period ${ }^{60}$.

It is worth noting that the $5^{\text {th }}$ century $\mathrm{AD}$ marked the emergence of a large force hostile to the existence of pagans and against pagan gods. This hostility against paganism was part of Christian culture, especially among monks and bishops ${ }^{61}$. The struggle between paganism and Christianity towards the end of the $4^{\text {th }}$ century $\mathrm{AD}$ in Petra continued later, despite the series of decrees issued by emperor Theodosius I prohibiting pagan practices and the construction of temples in the Byzantine Empire (especially the law issued on May $\left.25^{\text {th }}, 385 \mathrm{AD}\right)^{62}$.

The 419-422 AD journey of Barsauma, bishop of Nisibis ${ }^{63}$, along with 40 other Christian bishops revealed the presence of pagan ruins in the city of Petra and showed how the pagans in the city had been forced to convert to Christianity, especially in the time after the flood that hit the city ${ }^{64}$. The Church of Nisibis undertook to spread Christianity through missionary campaigns, including the one sent to $R Q M$ (Petra) to propagate the religion among the local population ${ }^{65}$. On the way, Barsauma noted that paganism was strong in the areas they passed; they were the masters of the country and the towns of the region, and they would close their cities' gates in his and his companions' faces ${ }^{66}$. As for Barsauma and his comrades, they headed for Palestine and the province of Arabia, destroyed the pagan temples (burning them down in the process), and demolished the Jewish temples ${ }^{67}$.

${ }^{59}$ J. McKenzie, Iconoclasm in Petra and the Other Nabataean Sites, [in:] Studies on the Nabataean Culture I. Refereed Proceedings of the International Conference on the Nabataean Culture, ed. N.I. KHAIRY, T.M. Weber, Amman 2013, p. 19.

${ }^{60}$ K.D. Politis, Nabataean Cultural..., p. 188.

${ }^{61}$ Z. Fiema, Reinventing the Sacred..., p. 34.

${ }^{62}$ H. Saradi, The Christianization..., p. 116-118. We find many examples of bishops and other Christians utilizing imperial decrees as a weapon in their struggle against the followers of paganism; such decrees were used as the driving force for them to destroy the pagan temples. This was particularly widespread in the Syria Secunda during the reign of emperor Theodosius I.

${ }^{63}$ Barsauma became bishop of Nisibis in 450 AD. He was a confidant of the Sasanian king Peroz I and a follower of Nestorianism. Z. Al-SAlameen, $R Q M=($ Raqeem $)$ in Historical and Epigraphic Sources, JSHS 31, 2015, p. 25.

${ }^{64}$ K.D. Politis, Nabataean Cultural..., p. 194.

${ }^{65}$ Z. Fiema, Late-Antique Petra..., p. 193; Z. Al-Salameen, RQM..., p. 25.

${ }^{66}$ D. CANER, History and Hagiography from the Late Antique Sinai. Including Translations of PseudoNilus' Narrations, Ammonius' Report on the Slaughter of the Monks of Sinai and Rhaithou, and Anastasius of Sinai's Tales of the Sinai Fathers, Liverpool 2010 [= TTH, 53], p. 14.

${ }^{67}$ G. Bowersock, Polytheism and Monotheism in Arabia and the Three Palestines, DOP 51, 1997, p. 3. 
He then headed for Petra by the Via Nova Traiana, which had been constructed by Roman emperor Trajan after the annexation of the Nabataean Kingdom into the Roman Empire in $106 \mathrm{AD}^{68}$. Barsauma states that paganism was widespread in the cities and areas they visited during their journey to Petra, and that the people of this city closed the gates preventing them from entering ${ }^{69}$, although some cities on their way opened their doors to them ${ }^{70}$. Barsauma remarks that when he arrived in Petra ${ }^{71}$, he found the gates closed and guarded by the local residents. He addressed them, saying: Let me approach you, do not let anyone hurt me. I am the youngest Christian. They have sent me a messenger to speak to you, the word of peace ${ }^{72}$. Barsauma continued his expedition into Petra after he was allowed to enter on condition that he would not hurt the inhabitants or the city, and that he would not burn their gods with fire ${ }^{73}$; this indicates that the city's inhabitants during this period were pagans.

Barsauma spoke to the people of the city about the wisdom of God and true faith, and that the God of the Christians was the one who had created them, who made rain fall, and who gave food to all flesh. Meanwhile, the people of the city answered that it was their gods who had created the sky and the earth, and that for four years no drop of rain had fallen. They challenged Barsauma, saying that if his God was the one who made rain fall, he should pray for him to make the rain fall on them; if this were to happen, they would become Christians ${ }^{74}$.

After hearing these words, Barsauma told the people that he and his companions would call on God to make the rain fall down on their city, and that if they failed, they would be free to stone them to death. Subsequently, Barsauma and his disciples went to pray, until the rain fell; the water drowned the city and its streets, even destroying its walls. The rain lasted for four days ${ }^{75}$. At this point, the inhabitants asked Barsauma to make his God stop the rain. He responded to them saying that in order to make the rain stop, they would have to renounce their deceitful idols and to acknowledge the God of the Christians. Then, the inhabitants shouted in one voice: We declare our innocence from our dead idols and acknowledge the living God. He then asked them to take their hammers and smash their misleading idols, and all the priests took the iron tools and destroyed the statues. Subsequently, Barsauma left the city safely, went to Sinai and prayed there ${ }^{76}$. Afterwards, he

${ }^{68}$ Z. Al-Salameen, RQM..., p. 25.

${ }^{69}$ W.D. Ward, From Provincia..., p. 249; Z. Al-Salameen, RQM..., p. 25.

${ }^{70}$ W.D. WARD, From Provincia..., p. 249.

${ }^{71}$ Barsauma mentions the old name of Petra, 'Reqem Dgaia' ('RQM Dgaia'), and says that it is the greatest city in the province of Palestina Tertia, W.D. WARd, From Provincia..., p. 249.

${ }^{72}$ Z. Al-Salameen, RQM..., p. 27.

${ }^{73}$ K.D. Politis, Nabataean Cultural..., p. 194; Z. Al-Salameen, RQM..., p. 27.

${ }^{74}$ Z. Al-Salameen, RQM..., p. 27.

${ }^{75}$ Z. Fiema et al., The Petra Church, Amman 2001, p. 3; Z. Al-Salameen, RQM..., p. 27.

${ }^{76} \mathrm{Z}$. AL-SALAmEen, RQM..., p. 27. Geological surveys using paleoflood reconstruction techniques indicate that Petra was hit by a destructive flood during the period of the $4^{\text {th }}-6^{\text {th }}$ century $\mathrm{AD}$. 
and his 40 companions travelled to Areopolis in Kerak, where they found a large temple called bitšbta, built of huge stones, with its roof and walls adorned with bronze, silver and gold. Inside, there was a range of luxurious arches, tables and candlesticks made of gold; its interior doors were made of bronze, while the outer gate was made of iron. He burned it down and prevented the theft of its contents. After this incident, Barsauma and his companions crossed Wadi al-Mujib and continued to destroy the temples in northern Jordan and Syria ${ }^{77}$. It is interesting to note that there is no indication of the presence of pagans in Petra after that date. In the course of this period Barsauma proceeded to destroy pagan and Jewish temples - roughly at the same time when emperor Theodosius II issued a regulation (in $423 \mathrm{AD}$ ) that prohibited the destruction or looting of pagan and Jewish temples $^{78}$. It seems that the law came as the Byzantine Empire's reaction to the deeds of this bishop, although - as we mentioned earlier - Theodosius II would later issue a decree (in $438 \mathrm{AD}$ ) quite contrary to the first one, stipulating the destruction of temples and ordering the prevention of pagan worship.

Bishop Barsauma and his companions' encounter with the pagan population of Petra is consistent with what Byzantine historian Jerome (347-420 AD) says about the missionary activities of bishop Hilarion ${ }^{79}$ (291-371 AD) in the vicinity of $\mathrm{Gaza}^{80}$. Sozomen confirms that his grandfather converted to Christianity through bishop Hilarion ${ }^{81}$. Jerome states that while Hilarion was in the desert to the south of Gaza, a group of residents of the vicinities of Aila, Jerusalem and Rhinocolura (Arish) came to him, seeking to be cured of diseases. Since he was able to treat them, these miracles increased his fame and many of the locals converted to Christianity. He was also credited with establishing monasteries in the region of Palestine ${ }^{82}$. Jerome adds that when he visited the city of Khalsa in the Negev with his disciples around $350 \mathrm{AD}$, he found people there holding a great celebration of the goddess Venus. When the people heard of the arrival of this blessed man, they came out with their wives and children to receive him, and when they saw him, they shouted and said to him 'Mubarak'. Hilarion received them with all humility and love, and called on them to worship God instead of stones; then he looked up at the sky, crying profusely, and promised to visit them again if they kept their faith in the Lord Christ. They allowed him to leave only after he had laid

The flood is described as sudden and destructive, reaching the height of 4-6 meters at the Siq entrance, T.R. PARADISE, The Great Flood of Petra. Evidence for a $4^{\text {th }}-5^{\text {th }}$ AD Century Catastrophic Flood, ADAJ 56, 2012, p. 143-158. This means that it occurred during the period when Barsauma visited Petra, which might confirm the narrative transmitted by this bishop.

${ }_{77}$ W.D. WARd, From Provincia..., p. 249.

${ }^{78}$ G. Bowersock, Polytheism..., p. 3.

${ }^{79}$ A bishop from Gaza who took upon himself the responsibility of Christian missionary activity, W.D. WARD, From Provincia..., p. 222.

${ }^{80}$ Ibidem.

${ }^{81}$ Sozomenus, V, 15, 227.

${ }^{82}$ W.D. WARD, From Provincia..., p. 226. 
the foundation for their church ${ }^{83}$. Altogether, it is clear that Hilarion's mission succeeded in making the Nabataeans as well as the inhabitants of Khalsa and of the nearby regions start their transition to Christianity. This task was later finished by bishop Barsauma.

The role of Hilarion and his miracles involving the healing of the sick was similar to that of bishop Barsauma and his miracles related to causing the rainfall. The local people would convert to Christianity after witnessing such miracles, especially since the visit of Hilarion was chronologically close to that of Barsauma. In the end, both bishops contributed to the victorious outcome of the mission.

\section{Religious changeover in Petra in the light of archeological evidence}

The names found in the Christian cemetery in the Ghor al-Safi region, dated to the period from the $4^{\text {th }}$ to the $6^{\text {th }}$ century $\mathrm{AD}$, indicate that a group of Christian citizens from Petra was buried there. Christian symbols such as crucifixes were found on their tombstones ${ }^{84}$. The inscriptions on these tombstones include e.g. the following: Monument of Anna daughter of Azizos from the city of Petra (427 AD), Monument of Kosmas son of Abdamochos from Petra (final quarter of the $4^{\text {th }}$ century AD) ${ }^{85}$. The analysis of archaeological finds and historical sources indicates that the process of transitioning to Christianity was completed among the population of Petra during the $6^{\text {th }}$ century AD. The Petra papyri dated between 527 and $582 \mathrm{AD}$ reveal the existence of a Christian community in the region during this period, with some of the inhabitants remaining pagan ${ }^{86}$. In many of the areas that were under Byzantine rule, such as Hawran and Golan, paganism was practiced side by side with the Christian religion ${ }^{87}$.

The archaeological excavations in the Wadi Farasa at Petra have uncovered the presence of triangular stones or tombstones bearing inscriptions in Greek, dating back to the $5^{\text {th }}$ century AD, along with pictures of groups of crosses surrounded by palm branches ${ }^{88}$. This indicates the existence of a Christian community in the $5^{\text {th }}$ century $\mathrm{AD}$, and the transition of the local population from pagan symbols to Christian ones.

The period from the late $4^{\text {th }}$ to the $6^{\text {th }}$ century AD witnessed the peak of the conversion of pagan sites and temples into churches ${ }^{89}$. One of the most significant

\footnotetext{
${ }^{83}$ Ibidem; D. CANER, History..., p. 16.

${ }^{84}$ Y. Meimaris, K. Kritikakou-Nikolaropoulou, Inscriptions from Palaestina Tertia. The Greek Inscriptions from Ghor es-Safi (Byzantine Zoom), Athens 2005, p. 32.

${ }^{85}$ Ibidem.

${ }^{86}$ P. Bikai, Petra Church Project, Petra Papyri, ADAJ 40, 1996, p. 487-489.

${ }^{87}$ C.M. Dauphin, Jewish and Christian Communities in the Roman and Byzantine Gaulanitis. A Study of Evidence from Archaeological Surveys, PEQ 114, 1982, p. 129-142.

${ }^{88}$ K.D. Politis, Nabataean Cultural..., p. 194.

${ }^{89}$ R. BAYLIss, Usurping the Urban Image..., p. 63.
} 
pieces of evidence for the transition of the population of Petra to Christianity is the inscription of the Urn Tomb (Fig. 1), from June $24^{\text {th }}, 446 \mathrm{AD}$. It refers to the conversion of the Urn Tomb into a church by Jason, the bishop of the city, and Julian, the deacon ${ }^{90}$. The inscription, found on one of the interior corners of the mausoleum, reads: In the time of the most holy bishop Jason this place was dedicated [...] to Christ the Saviour ${ }^{11}$.

This religious transition from paganism to Christianity - as some scholars see it - reveals the power of the new ethos in the city of Petra in the face of paganism ${ }^{92}$. The niches found in the eastern wall of the Urn Tomb were expanded to create the nave for the church, while a number of subterranean arches were added in the western end of the mausoleum ${ }^{93}$.

The turning of the Urn Tomb into a church during this period gives the impression that the number of Christians in Petra was still limited after the visit of bishop Barsauma to the city. The Christians' inability to build their own church may also be indicative of hard economic conditions that made it impossible to undertake such an enterprise $e^{94}$.

Some scholars believe that the conversion of pagan temples to churches was generally uncommon in Palestine during the Byzantine period. However, stones from ruined temples were widely used to build new churches ${ }^{95}$. Christians seemed to have had two ways of dealing with pagan temples: either to destroy them entirely or to modify some of the architectural features of the existing buildings in accordance with the nature of Christianity.

Archaeological surveys point to the conversion of the royal tomb in Petra, known as the ed-Deir, into a Christian monastery at an unspecified time ${ }^{96}$. This monastery had been used by the Nabataeans as a place for holding their religious rites ${ }^{97}$. The inscriptions found near the monastery (featuring a set of crosses carved into the rock and dating back to the $5^{\text {th }}$ century $\mathrm{AD}$ ) indicate that it was used by Christians ${ }^{98}$. These new churches in the Urn Tomb and the Monastery, carved deep into the rock, were not affected by the earthquakes that hit Petra later on; they have remained virtually unchanged till today ${ }^{99}$.

${ }^{90}$ Y. Meimaris, Chronological Systems in Roman-Byzantine Palestine and Arabia. The Evidence of the Dated Greek Inscriptions, Athens 1992, p. 213; Z. Fiema, Late-Antique Petra..., p. 193.

${ }^{91}$ J. TAYlor, Petra and the Lost Kingdom of the Nabataeans, Cambridge 2012, p. 204.

${ }^{92}$ C. CoüAsnon, The Church of the Holy Sepulchre in Jerusalem, London 1974, p. 161.

${ }^{93}$ Z. Fiema, Late-Antique Petra..., p. 195; K.D. Politis, Nabataean Cultural..., p. 194.

${ }^{94}$ P. BikaI, The Churches of Byzantine Petra, NEA 65, 2002, p. 272.

${ }^{95}$ Z. Fiema, Late-Antique Petra..., p. 220.

${ }^{96}$ A. Lahelma, Z. Fiema, From Goddess to Prophet. 2000 Years of Continuity on the Mountain of Aaron near Petra, Jordan, Tem 44, 2008, p. 215.

${ }^{97}$ J.F. Healey, The Religion..., p. 47-50.

${ }^{98}$ A. Lahelma, Z. Fiema, From Goddess..., p. 215.

${ }^{99}$ W.D. WARD, From Provincia..., p. 226. 
J. McKenzie emphasizes that the Nabataeans did not destroy or erase faces of stone sculptures if they were not acceptable to them; they would not have made them because they knew that they were destined for obliteration ${ }^{100}$. Here, it seems important to point out that the earthquake that hit the region on May $19^{\text {th }}$, $363 \mathrm{AD}$ had the greatest impact on the demolition of many of Petra's landmarks ${ }^{101}$ : more than a third of the city was shattered, including the Temple of the Winged Lions, the Great Temple, and the Qasr el-Bint Temple. The destruction of these temples was a major blow to the pagan practices in Petra at the end of the $4^{\text {th }}$ century $\mathrm{AD}^{102}$. Kenneth $\mathrm{W}$. Russell notes that this earthquake affected most areas of Petra and its surroundings, such as the Temple of Kherbit el-Tannur, as well as the buildings in the Negev area, such as Mempsis ${ }^{103}$.

It is evident from the archaeological evidence that the spread of Christianity in the $4^{\text {th }}$ century $\mathrm{AD}$ was not the main factor in ending paganism in Petra; rather, it was the earthquake of $363 \mathrm{AD}$ and the ensuing destruction of the region that played the decisive role in the demolishing of the pagan temples ${ }^{104}$. The archaeological material also indicates that three Nabataean temples, the temple of Khirbet et-Tannur and the temple of Khirbet ed-Dharih ${ }^{105}$ kept on practicing the worship of paganism after the transition to Christianity and the destruction of the area in the earthquakes ${ }^{106}$. Martha Joukowsky believes that the Great Temple in Petra kept being used by the pagans until the beginning of the $4^{\text {th }}$ century $\mathrm{AD}^{107}$. Similarly, the Temple of Qasr el-Bint in Petra remained open until the second half of the $4^{\text {th }}$ century $\mathrm{AD}$, when it was destroyed in the earthquake of $363^{108}$. This means that the Christian community in Petra did not actively work to dispose of the pagan temples that existed in the city, and that the pagans were allowed to practice their rituals for an extended period of time. Pagan temples in Petra were abandoned gradually during the later periods. The earthquake that hit Petra in $419 \mathrm{AD}$ had a great impact on the destruction of the city's landmarks in that the ruins of these buildings were never restored ${ }^{109}$.

\footnotetext{
${ }^{100}$ J. McKenZie, Iconoclasm..., p. 20.

${ }^{101}$ Z. Fiema, S. Schmid, Nabataean Basileia and the Earthquake of AD 363 at Petra. Some Consideration, Man 17, 2014, p. 419.

${ }^{102}$ S.P. BRocк, A Letter Attributed to Cyril of Jerusalem on the Rebuilding of the Temple, BSOAS 40, 1977, p. 267-286.

${ }^{103}$ K.W. Russell, The Earthquake of May 19, AD 363, BASOR 238, 1980, p. 47. A later earthquake, which struck the city in the year 551, also caused the destruction of many of the landmarks in Petra, ibidem, p. 48.

${ }^{104}$ W.D. WARD, The 363 Earthquake..., p. 134.

${ }^{105}$ The archeological evidence suggests that the temples of Khirbet edh-Dharih and Khirbet et-Tannor were deserted at the same time after the earthquake of $363 \mathrm{AD}$, but at an unspecified period in the $6^{\text {th }}$ century AD, ibidem, p. 142.

${ }^{106}$ Ibidem, p. 134.

${ }^{107}$ M. Joukowsky, The Great Temple..., p. 222.

${ }^{108}$ F. ZAYAdine, Recent Excavations..., p. 249.

${ }^{109}$ Z. Fiema, Late-Antique Petra..., p. 222.
} 


\section{Churches in Petra}

The $4^{\text {th }}$ and $5^{\text {th }}$ centuries $\mathrm{AD}$ saw an increase in human settlement in the areas of Jordan in general, and Petra in particular ${ }^{110}$. This led to the local people's endeavors to establish churches, chapels and monasteries ${ }^{111}$. The $6^{\text {th }}$ century also witnessed the peak in the construction of churches in such provinces of the Byzantine Empire as the Provincia Arabia and the Palaestina Salutaris; this continued until the Umayyad and Abbasid periods ${ }^{12}$.

It is evident from the construction of the churches in Petra and their decoration with mosaic floors, as well as the use of marble in their construction, that these enterprises were funded by donors from the local population ${ }^{113}$. Archaeological excavations have revealed the presence of stones belonging to the Great Temple in Petra. The faces on the temple were erased so that the elements could be reused in the building of the Main Church ${ }^{114}$. After the transition of the local population to Christianity, the people worked to rehabilitate and reuse the Khirbet edh-Dharih and Khirbet et-Tannur temples as churches; thus, they preserved the images of stone statues and of living organisms which had been there before ${ }^{115}$.

The composition of the churches in Petra shows that the local inhabitants used the stones of the temples that were destroyed as a result of the earthquake in $363 \mathrm{AD}^{116}$. Facade stones bearing the image of a goddess (Aphrodite), found in street columns, were used in the construction of the church ${ }^{117}$.

Archaeological excavations have revealed the existence of three churches in Petra, opposite the Great Temple ${ }^{118}$, as well as a church attached to the Christian monastery in Jabal Hārūn ${ }^{119}$ (Fig. 2). The Petra papyri have made it clear that ecclesiastical figures - such as deacons, bishops and priests - played an important role in the city's community, intervening in matters such as disputes among the inhabitants, the distribution of water, and the leasing of agricultural lands ${ }^{120}$. This shows the prominent status of the Church in the daily life of Petra Christians.

\footnotetext{
${ }^{110}$ Ibidem, p. 192-193; Z. Fiema, Economics, Administration..., p. 17-35.

${ }^{111}$ T.S. Parker, An Empire's New Holy Land. The Byzantine Period, NEA 62, 1999, p. 138.

${ }^{112}$ L. Habas, Crosses in the Mosaic Floors of Churches in Provincia Arabia and Nearby Territories, Against the Background of the Edict of Theodosius II, JMR 8, 2015, p. 33-60.

${ }^{113}$ Z. Fiema, Late-Antique Petra..., p. 220.

${ }^{114} \mathrm{~J}$. McKenZIE, Iconoclasm..., p. 14.

${ }^{115}$ Ibidem.

${ }^{116}$ W.D. WARD, The 363 Earthquake..., p. 133. This was by the end of the $4^{\text {th }}$ and the beginning of the $6^{\text {th }}$ century AD.

${ }^{117}$ Z. Fiema, Late-Antique Petra..., p. 219.

${ }^{118}$ Ibidem, p. 227.

${ }^{119} \mathrm{Ibidem}$. Jabal al-Nabī Hārūn is $5 \mathrm{~km}$ to the south-east of Petra, about $1255 \mathrm{~m}$ above the sea level. It is the highest mountain in Petra and its name was associated with prophet Harun, brother of prophet Moses, G. Peterman, R. Schick, The Monastery of Saint Aaron, ADAJ 40, 1996, p. 473-480.

${ }^{120}$ Z. Fiema, Late-Antique Petra..., p. 227.
} 
All three Petra churches are located in one place. It remains unknown, however, why the Christians did not build their churches over the three pagan temples which symbolized paganism in the city - i.e. the Temple of Qasr el-Bint, the Temple of the Winged Lions, and the Great Temple. It seems that the increase in the Christian population in Petra prompted the faithful to convert the Urn Tomb and the Monastery into churches, in addition to building new churches that met the spiritual and religious needs of the people. As regards design, the architects and bishops followed the basilica system when building churches in Petra, with the admixture of local customs, with no long-established designs ${ }^{121}$. The construction of the three churches that have been discovered (so far) shows that the Christians aimed to locate their churches in the center of the city, not in marginal areas far from there.

The first church, measuring $15 \times 25$ m, was called the Main Church (Fig. 3). It was erected between the $4^{\text {th }}$ and the $5^{\text {th }}$ century $\mathrm{AD}^{122}$ and continued to be used until the end of the $6^{\text {th }}$ century, as evidenced by the various papyri related to the church, found charred in a chamber next to the building ${ }^{123}$. The papyri explain that this church was built in honor of the "blessed and all holy Lady, the most glorious Mother of God, and ever virgin Mary' ${ }^{124}$. The Church of Petra is considered one of the most outstanding churches that have preserved their state and the mosaics contained inside. Some columns and stones from old Nabataean buildings were reused to build this church ${ }^{125}$. Inside, there was a small basin used for baptizing children and even pagan adults who converted to Christianity ${ }^{126}$.

The examination of the layers of the church floor shows that the area in which it was constructed had been used during the Nabataean period from the $1^{\text {st }}$ century $\mathrm{BC}$ to the $4^{\text {th }}$ century $\mathrm{AD}^{127}$. Patricia Bikai opines that the area in which the Main Church of Petra was built had witnessed military settlement during the Nabataean and Roman periods ${ }^{128}$. The analysis of the construction layers has also yielded evidence for Byzantine settlement in the area of the church from 363 AD until the middle of the $5^{\text {th }}$ century $\mathrm{AD}^{129}$. The use of this church continued at least until the end of the $6^{\text {th }}$ or even the beginning of the $7^{\text {th }}$ century $\mathrm{AD}^{130}$. The ongoing

${ }^{121}$ C. Coüasnon, The Church..., p. 167.

122 J. TAYLOR, Petra and the Lost..., p. 197.

${ }^{123}$ A. Arjava, M. Buchholz, T. Gagos, M. Kaimio, The Petra Papyri IV, Amman 2011, p. 23;

P. BIKAI, The Ridge Church at Petra, ADAJ 40, 1996, p. 481-486.

${ }^{124}$ Z. Fiema et al., The Petra Church..., p. 42-43.

${ }^{125}$ Ibidem, p. 172-173; P. Bikai, M. Perry, Petra North Ridge Tombs 1 and 2. Preliminary Report, BASOR 324, 2001, p. 59-78.

${ }^{126}$ J. TAYLOR, Petra and the Lost..., p. 197.

${ }^{127}$ Z. Fiema et al., The Petra Church..., p. 10-13.

${ }^{128}$ P. BikaI, The Churches of Byzantine..., p. 271.

${ }^{129}$ Z. Fiema et al., The Petra Church..., p. 97.

${ }^{130} \mathrm{Ibidem}$, p. 306. 
Christian presence in Petra during the $6^{\text {th }}$ century shows that this church was restored by the local Christian population.

The second Christian Church, known as the Blue Church (Fig. 4), is located between the Main and Ridge Churches. Archaeological surveys have shown that it was built on the ruins of a military barracks used during the Nabataean and Roman periods, but it was later reused by the Petra Christians ${ }^{131}$.

The construction of the church dates back to the same period in which the Main Church was built, i.e. the $4^{\text {th }}-5^{\text {th }}$ century $\mathrm{AD}^{132}$. Archaeological research at the site has revealed a number of blue marble blocks used in the manufacturing of the church pulpit, in addition to the chancel screens ${ }^{133}$. In fact, the church was called the Blue Church precisely because of the use of four Egyptian blue marble columns stemming from the Nabataean period ${ }^{134}$. The comparison of this church with the other churches in Petra shows that it is small in size - its area does not exceed $111 \mathrm{~m}^{2}$, while the Main Church boasts $358 \mathrm{~m} 2$ and the Ridge Church $158 \mathrm{~m}^{2}$. This indicates either that the Blue Church served smaller Christian groups or that its use was restricted to the upper-class faithful. The church continued to be used until it was destroyed by the earthquake of $748 \mathrm{AD}^{135}$.

The original name of third church is not known; it is therefore referred to as the Ridge Church (Fig. 5) ${ }^{136}$. Measuring $13.5 \times 18 \mathrm{~m}$, it was built according to the basilica system and features one semi-circular apse and a nave; the apse was decorated with colorful mosaic pieces ${ }^{137}$. It dates back to the end of the $4^{\text {th }}$ or the beginning of the $5^{\text {th }}$ century $\mathrm{AD}^{138}$, which makes it the oldest currently known church in Petra; it was built on the ruins of an unidentified temple-like structure, whose stones were used in the building of the church ${ }^{139}$. The archeological findings from the site include a stone used in the construction of the church bearing an engraved gift-related inscription in Latin, evidently written by a Roman soldier; this text dates roughly to the end of the $3^{\text {rd }}$ century $\mathrm{AD}^{140}$. This indicates that the building may have been constructed at that time, especially given the presence of a Christian sect in Petra.

The church is located at the northern edge of the Main and Blue Churches ${ }^{141}$. This church, like all others in Petra, contains a semi-circular apse, a courtyard and

${ }^{131}$ P. BikAI, The Churches of Byzantine..., p. 271.

${ }^{132}$ Ibidem.

${ }^{133}$ Ibidem, p. 274.

${ }^{134}$ P. Bikai, M. Perry, Petra North Ridge..., p. 59-78.

${ }^{135}$ Ibidem, p. 66.

${ }^{136}$ P. BikaI, The Ridge Church..., p. 481.

${ }^{137}$ Z. Fiema, Late-Antique Petra..., p. 220.

${ }^{138}$ Ibidem.

${ }^{139}$ P. BiKaI, The Ridge Church..., p. 484.

${ }^{140}$ IdEm, The Churches of Byzantine..., p. 271.

${ }^{141}$ Ibidem. 
two northern and southern aisles, with five columns separating the northern and southern aisles from the church. It is also directed eastwards ${ }^{142}$. Some researchers report that the columns and capitals used in the construction of the Main and Ridge Churches were drawn from ancient Nabataean buildings and reused for the new Christian temples ${ }^{143}$.

It seems that this church was built immediately after the earthquake of the year $363 \mathrm{AD}$; this is indicated by the presence of an apse and side chambers dating back to the period following the earthquake ${ }^{144}$. Archaeological explorations have revealed that the area on which the church was built had been a Nabataean cemetery (Fig. 5) ${ }^{145}$.

The three Petra churches were renovated during the $6^{\text {th }}$ century $\mathrm{AD}$, and together they constituted the Christian council complex of Petra. The floors of these churches were paved with expensive marble panels; it seems that such kind of flooring was found only in important churches in the area ${ }^{146}$. This testifies to the existence of a rich class within the Christian community of Petra during the $5^{\text {th }}$ and $6^{\text {th }}$ centuries $\mathrm{AD}^{147}$. The use of these churches continued until the end of the $6^{\text {th }}$ century AD, when the Christian population of Petra decreased, especially after the decline in the interest in maintaining the city's infrastructure and the destruction of the channels that provided it with water.

Another church, measuring ca. $22.6 \times 13.6 \mathrm{~m}$, was found attached to a large monastery. Its area is ca. $62 \mathrm{~m}$ north-south $\mathrm{x} 48 \mathrm{~m}$ east-west in the Jabal al-Nabi Hārun region. It dates back to the end of the $5^{\text {th }}$ century $\mathrm{AD}$. This church was built in accordance with the basilica system ${ }^{148}$, on the ruins of a Nabataean temple from the $1^{\text {st }}$ century $\mathrm{AD}^{149}$.

The Nabataean pilgrims visiting the shrine of prophet Harun were used to praying and sacrificing for the Isis betyl in Wadi Abu Ullayqa in Petra ${ }^{150}$. It seems that the goddess Isis was worshiped in the region of Jabal Hārūn, especially given the presence of her images in the valley of Abu Ullayqa on the road leading to the mountain. The name of Isis was associated with fertility and agriculture, and this may apply to the area near Jabal Hārūn, which was characterized by the presence of ample agricultural lands - still cultivated today by the local residents ${ }^{151}$. The

\footnotetext{
${ }^{142}$ Ibidem.

${ }^{143}$ Z. Fiema et al., The Petra Church..., p. 172-173.

${ }^{144}$ P. BikaI, The Churches of Byzantine..., p. 271.

${ }^{145}$ M. Perry, Life and Death in Nabataea. The North Ridge Tombs and Nabataean Burial Practices, NEA 65, 2002, p. 265.

${ }^{146}$ P. BikaI, The Churches of Byzantine..., p. 273.

${ }^{147}$ R. SCHICK, Christianity at Humayma, Jordan, SBF.LA 45, 1995, p. 340.

${ }^{148}$ Z. Fiema, Late-Antique Petra..., p. 220; Z. Fiema, R. Holmgren, The Byzantine Monastic/Pilgrimage Center of St. Aaron near Petra, [in:] Petra. A City..., p. 101.

${ }^{149} \mathrm{Ibidem}$. This temple was dedicated to the worship of the god el-'Uzza.

${ }^{150}$ A. Lahelma, Z. Fiema, From Goddess..., p. 208.

${ }^{151}$ N. HeIska, The Economy and Livelihoods of the Early Christian Monasteries in Palestine (unpublished M.A thesis, University of Helsinki, 2003), p. 40.
} 
location of the Christian monastery near the shrine and in the vicinity of the agricultural areas suggests that the monastery was used by the Christians for residential purposes, especially following the destruction of the Nabataean temple in the earthquake of $363 \mathrm{AD}$.

The monastery and the church that were found in Jabal Hārūn were associated with the transition of the population from paganism to Christianity at an early period of the religion's history ${ }^{152}$. Christian pilgrims would come to Jabal Hārūn (in the region forming the southern part of Petra) starting in the $4^{\text {th }}$ century $\mathrm{AD}$, even before the earthquake of $363 \mathrm{AD}$ - i.e. during the period when the Nabataeans worshiped there ${ }^{153}$. Pagans and Christians continued to visit Jabal Hārūn until the $5^{\text {th }}$ century $\mathrm{AD}$, when the church was built and the pagan practices were discontinued. It seems that the Christians diligently removed all the monuments that reminded them of paganism in the course of the construction ${ }^{154}$. Archaeological research in Mount Haroun has shown that some parts of the Christian monastery continued to be used until the end of the Late Byzantine period and the beginning of the Islamic period ${ }^{155}$.

Some scholars mention that during the period between the $5^{\text {th }}$ and $6^{\text {th }}$ centuries $\mathrm{AD}$, the bishops and monks of Petra wiped out some of the features and aspects of pagan gods, in a symbolic gesture proving that Christianity had vanquished the pagan gods in Petra ${ }^{156}$. Thus, the images of the goddess Isis carved in Wadi Abu Ullayga were destroyed by hammers, with her heads being broken ${ }^{157}$. Some of the monuments in the Qattar ad-Dayr area of Petra were also distorted and the betyl converted into a cross ${ }^{158}$. The fact that the Christians decided to efface these pagan elements in Petra could indicate that the latter were still somehow powerful in the society; however, it may also simply mean that the Christians wanted to show the triumph of their faith over paganism in the city ${ }^{159}$.

Consequently, we conclude that although Petra was the capital of the province of Palaestina Salutaris, and that the shrine of prophet Harun near Petra was a pilgrimage destination, the transition to Christianity in the city did not differ in essence from those undergone by the remaining pagan societies in the Byzantine Empire. It should be borne in mind that by the $6^{\text {th }}$ century $\mathrm{AD}$, pagans became a minority not only in Petra but also in the Empire as a whole.

\footnotetext{
152 Z. Fiema, Reinventing the Sacred..., p. 32.

${ }^{153}$ Ibidem.

${ }^{154}$ Z. Fiema, R. Holmgren, The Byzantine..., p. 102.

155 Z. Fiema, Reinventing the Sacred..., p. 32.

${ }^{156}$ R. Wenning, The Betyls of Petra, BASOR 324, 2001, p. 82; W.D. WARD, The 363 Earthquake..., p. 134.

${ }^{157}$ M.-J. Roche, A Nabataean shrine to Isis in Wādì Abū 'Ullayqah, in the South-West of Petra, PSAS 42,2012 , p. 55-71.

${ }^{158}$ R. Wenning, The Betyls of Petra..., p. 82.

${ }^{159}$ W.D. WARD, The 363 Earthquake..., p. 134.
} 


\section{Conclusion}

The archaeological material discovered in Petra in particular - and in other Nabataean areas in general - has provided us with material indispensable for increasing our understanding of the transition of the Petra community from paganism to Christianity. This transformation included the accompanying changes in culture and in the Christians' view of paganism.

Crucially, the advent of Christianity in the $4^{\text {th }}$ century $\mathrm{AD}$ did not lead to the eradication of paganism from the minds and culture of the people. Rather, paganism continued to exist in the ensuing centuries, even after the destruction of the pagan buildings in Petra due to the earthquake of $363 \mathrm{AD}$ and the demise of the last Byzantine emperor who supported paganism - Julian. Such a situation is reflected in the Christian sources, which speak about the existence of certain pagan elements and sects that still practiced their rituals until a very late time in Petra. This is tantamount to the survival of a minority of pagans who managed to preserve their ancient religion. It seems that these were a small number of Bedouin Saracens, who were not under the control of the Byzantine Empire (especially during the $6^{\text {th }}$ century $\mathrm{AD}$ ).

The Petra papyri show that the Main Church remained open until the end of the $6^{\text {th }}$ or even the beginning of the $7^{\text {th }}$ century AD. This indicates the existence of a Christian society that fully exercised its functions and was integrated into the Byzantine Empire.

\section{Bibliography}

\section{Primary Sources}

Eusebius' Life of Constantine, trans. et ed. A. Cameron, S. Hall, Oxford 1999 [= Clarendon Ancient History Series].

Das Onomastikon der biblischen Ortsnamen, ed. E. Klostermann, Hildesheim 1966.

The Panarion of Epiphanius of Salamis. Books II and III, De fide, trans. F. WiLliams, ${ }^{2}$ Leiden-Boston 2013 [= Nag Hammadi and Manichaean Studies, 79].

Sozomenus, Church History from AD 323-425, trans. C.D. HartranfT, [in:] Nicene and Post-Nicene Fathers of Christian Church II, vol. II, ed. P. Schaff, H. Wace, New York 1890, p. 179-454.

Strabo, Geography, trans. H.L. Jones, London 1932 [= Loeb Classical Library, 49].

Theodoret, Kirchengeschichte, ed. L. Parmentier, Berlin 1954 [= Die griechischen christlichen Schriftsteller der ersten drei Jahrhunderte, 44].

\section{Secondary Literature}

Alpass P., The Religious Life of Nabataea, Leiden-Boston 2013 [= Religions in the Graeco-Roman World, 175].

Arjava A., Buchholz M., Gagos T., Kaimio M., The Petra Papyri IV, Amman 2011. 
Avner U., Nabataean Standing Stones and Their Interpretation, "ARAM Periodical" 11-12, 19992000, p. 97-122.

BAILEY R.A., The Structure of Paul's Letters, 2010, www.inthebeginning.org/structure/complete.pdf [8 X 2018].

Bar D., The Christianisation of Rural Palestine during Late Antiquity, "Journal of Ecclesiastical History" 54, 2003, p. 401-421.

Barnes T.D., Athanasius and Constantius. Theology and Politics in the Constantinian Empire, Cambridge Massachusett 2001.

Bayliss R., Usurping the Urban Image. The Experience of Ritual Topography in Late Antique Cities of the Near East, [in:] TRAC 98. Proceedings of the Eighth Annual Theoretical Roman Archaeology Conference, Leicester 1998, ed. P. BAKer, C. Forcey, S. Jundi, R. Witcher, Oxford 1999, p. 59-71.

Bikai P., The Churches of Byzantine Petra, "Near Eastern Archaeology" 65, 2002, p. 271-276.

Bikai P., Petra Church Project, Petra Papyri, "Annual of the Department of Antiquities of Jordan" 40, 1996, p. 487-489.

Bika P., The Ridge Church at Petra, "Annual of the Department of Antiquities of Jordan" 40, 1996, p. 481-486.

Bikai P., Perry M., Petra North Ridge Tombs 1 and 2. Preliminary Report, "Bulletin of the American Schools of Oriental Research in Jerusalem and Baghdad" 324, 2001, p. 59-78.

Bowersock G., Polytheism and Monotheism in Arabia and the Three Palestines, "Dumbarton Oaks Papers" 51, 1997, p. 1-10.

Briggs C.W., The Apostle Paul in Arabia, "Biblical World" 41, 1913, p. 255-259.

BRock S.P., A Letter Attributed to Cyril of Jerusalem on the Rebuilding of the Temple, "Bulletin of the School of Oriental and African Studies" 40, 1977, p. 267-286.

CANer D., History and Hagiography from the Late Antique Sinai. Including Translations of Pseudo-Nilus' Narrations, Ammonius' Report on the Slaughter of the Monks of Sinai and Rhaithou, and Anastasius of Sinai's Tales of the Sinai Fathers, Liverpool 2010 [= Translated Texts for Historians, 53].

CoüASNON C., The Church of the Holy Sepulchre in Jerusalem, London 1974.

DAuphin C.M., Jewish and Christian Communities in the Roman and Byzantine Gaulanitis. A Study of Evidence from Archaeological Surveys, "Palestine Exploration Quarterly" 114, 1982, p. 129-142.

Fiema Z., The Byzantine Church at Petra, [in:] Petra Rediscovered. Lost City of the Nabataeans, ed. G. Markoe, New York 2003, p. 239-249.

Fiema Z., Economics, Administration and Demography of Late Roman and Byzantine Southern Transjordan (unpublished doctoral dissertation, University of Utah, 1991).

Fiema Z., From the Annexation to Aaron. Petra in Roman and Byzantine Times, [in:] Petra. A City Forgotten and Rediscovered, ed. J. Frösen, Z. Fiema, Helsinki 2002, p. 60-73.

Fiema Z., The Islamic Conquest of Southern Jordan. A New Research Perspective, "Annual of the Department of Antiquities of Jordan" 36, 1992, p. 325-331.

Fiema Z., Late-Antique Petra and Its Hinterland. Recent Research and New Interpretations, [in:] The Roman and Byzantine Near East, vol. III, ed. N. Humphrey, Portsmouth 2002 [= Journal of Roman Archaeology. Supplementary Series, 31], p. 191-252.

Fiema Z., Reinventing the Sacred. From Shrine to Monastery at Jabal Hārūn, "Proceedings of the Seminar for Arabian Studies" 42, 2012, p. 27-37. 
Fiema Z., Holmgren R., The Byzantine Monastic/Pilgrimage Center of St. Aaron near Petra, [in:] Petra. A City Forgotten and Rediscovered, ed. J. Frösen, Z. Fiema, Helsinki 2002, p. 99-111.

Fiema Z., Schmid S., Nabataean Basileia and the Earthquake of AD 363 at Petra. Some Consideration, "Mediterraneo antico" 17, 2014, p. 419-432.

Fiema Z. et al., The Petra Church, Amman 2001.

Habas L., Crosses in the Mosaic Floors of Churches in Provincia Arabia and Nearby Territories, Against the Background of the Edict of Theodosius II, "Journal of Mosaic Research" 8, 2015, p. 33-60.

Hammond P.C., The Temple of the Winged Lions, [in:] Petra Rediscovered. Lost City of the Nabataeans, ed. G. Markoe, New York 2003, p. 223-229.

Harnack A., The Mission and Expansion of Christianity in the First Three Centuries, vol. II, trans. et ed. J. Moffatt, New York 1908.

HeAley J.F., The Religion of the Nabataeans. A Conspectus, Leiden 2001 [= Religions in the Graeco-Roman World, 136].

Heiska N., The Economy and Livelihoods of the Early Christian Monasteries in Palestine (unpublished M.A thesis, University of Helsinki, 2003).

Hengel M., Paul in Arabia, "Bulletin for Biblical Research" 12, 2002, p. 47-66.

Joukowsky M., The Great Temple, [in:] Petra Rediscovered. Lost City of the Nabataeans, ed. G. Markoe, New York 2003, p. 214-222.

Lahelma A., Fiema Z., From Goddess to Prophet. 2000 Years of Continuity on the Mountain of Aaron near Petra, Jordan, “Temenos” 44, 2008, p. 191-222.

Macdonald B., What Happened to the Nabataeans? The Literary and Archaeological Evidence, [in:] Studies on the Nabataean Culture II. Refereed Bulletin of the International Conference on the Nabataean Culture, ed. N.I. KHAIRY et al., Amman 2016, p. 177-196.

McKenzie J., Iconoclasm in Petra and the Other Nabataean Sites, [in:] Studies on the Nabataean Culture I. Refereed Proceedings of the International Conference on the Nabataean Culture, ed. N.I. Khairy, T.M. Weber, Amman 2013, p. 1-27.

Meimaris Y., Chronological Systems in Roman-Byzantine Palestine and Arabia. The Evidence of the Dated Greek Inscriptions, Athens 1992.

Meimaris Y., Kritikakou-Nikolaropoulou K., Inscriptions from Palaestina Tertia. The Greek Inscriptions from Ghor es-Safi (Byzantine Zoom), Athens 2005.

Murray M., Religion and the Nomadic Lifestyle. The Nabateans, [in:] Travel and Religion in Antiquity, ed. P.A. Harland, Waterloo Ontario 2001, p. 215-234 [= Studies in Christianity and Judaism, 21].

Negev A., The Chronology of the Middle Nabatean Period, "Palestine Exploration Quarterly" 101, 1969 , p. 5-14.

Paradise T.R., The Great Flood of Petra. Evidence for a $4^{\text {th }}-5^{\text {th }} A D$ Century Catastrophic Flood, "Annual of the Department of Antiquities of Jordan" 56, 2012, p. 143-158.

Parker T.S., An Empire's New Holy Land. The Byzantine Period, "Near Eastern Archaeology" 62, 1999, p. 134-180.

Perry M., Life and Death in Nabataea. The North Ridge Tombs and Nabataean Burial Practices, "Near Eastern Archaeology" 65, 2002, p. 265-270.

Peterman G., Schick R., The Monastery of Saint Aaron, "Annual of the Department of Antiquities of Jordan" 40, 1996, p. 473-480. 
Politis K.D., Nabataean Cultural Continuity into the Byzantine Period, [in:] The World of the Nabataeans. Volume 2 of the International Conference The World of the Herods and the Nabataeans held at the British Museum, 17-19 April 2001, ed. K.D. Politis, London 2007, p. 187-200.

Roche M.-J., A Nabataean shrine to Isis in Wädī Abū 'Ullayqah, in the South-West of Petra, "Proceedings of the Seminar for Arabian Studies" 42, 2012, p. 55-71.

Russell K.W., The Earthquake of May 19, AD 363, "Bulletin of the American Schools of Oriental Research in Jerusalem and Baghdad" 238, 1980, p. 47-64.

Al-Salameen Z., Introduction to History and Civilization of Petra, Amman 2010.

AL-SALAmeen Z., RQM = (Raqeem) in Historical and Epigraphic Sources, "Journal of the Saudi Historical Society" 31, 2015, p. 7-35.

Saradi H., The Christianization of Pagan Temples in the Greek Hagiographical Texts, [in:] From Temple to Church. Destruction and Renewal of Local Cultic Topography in Late Antiquity, ed. J. Hahn, S. Emmel, U. Gotter, Leiden 2008 [= Religions in the Graeco-Roman World, 163], p. 113-134.

Saradi-Mendelovici H., Christian Attitudes toward Pagan Monuments in Late Antiquity and Their Legacy in Later Byzantine Centuries, "Dumbarton Oaks Papers" 44, 1990, p. 47-61.

Sсніск R., Christianity at Humayma, Jordan, "Studium biblicum franciscanum: Liber annuus" 45, 1995, p. 319-342.

Schmitt-Korte K., An Early Christian Record of the Nabataeans. The Maslam Inscription (ca. 350 $A D)$, "ARAM Periodical" 2, 1990, p. 123-142.

Shahid I., Byzantium and the Arabs in the Fourth Century, Washington 1984.

Smith R., Arabia, [in:] The Anchor Bible Dictionary, vol. I, ed. D. Freedman, New York-London 1992.

TABbernee W., Early Christianity in Contexts. An Exploration across Cultures and Continents, Grand Rapids 2014.

TAYLOR J., Petra and the Lost Kingdom of the Nabataeans, Cambridge 2012.

Teixidor J., The Pagan God. Popular Religion in the Greco-Roman Near East, Princeton 1977.

VRIES DE B., Between the Cults of Syria and Arabia. Traces of Pagan Religion at Umm al-Jimal, "Studies in the History and Archaeology of Jordan" 10, 2009, p. 177-191.

Ward W.D., From Provincia Arabia to Palaestina Tertia. The Impact of Geography, Economy, and Religion on Sedentary and Nomadic Communities in the Later Roman Province of Third Palestine (unpublished doctoral dissertation, University of California, 2008).

WARD W.D., The 363 Earthquake and the End of Public Paganism in the Southern Transjordan, "Journal of Late Antiquity" 9, 2016, p. 132-170.

Wenning R., The Betyls of Petra, "Bulletin of the American Schools of Oriental Research in Jerusalem and Baghdad” 324, 2001, p. 79-95.

Wenning R., North Arabian Deities and the Deities of Petra. An Approach to the Origins of the Nabataeans, [in:] Men on the Rock. The Formation of Nabataean Petra, ed. S.G. Schmid, M. Mouton, Berlin 2013, p. 335-342.

Zayadine F., The Nabataean Gods and Their Sanctuaries, [in:] Petra Rediscovered. Lost City of the Nabataeans, ed. G. MarkoE, New York 2003, p. 57-64.

Zayadine F., Recent Excavations and Restoration at Qasr el Bint of Petra, "Annual of the Department of Antiquities of Jordan" 29, 1985, p. 239-250.

Zayadine F., Farajat S., Excavation and Clearance at Petra and Beida, "Annual of the Department of Antiquities of Jordan" 35, 1991, p. 275-311. 


\begin{abstract}
The aim of this paper is to shed some light on the period of Petra's passage from paganism to Christianity, which saw the deterioration of pagan beliefs and the struggle for survival between paganism and Christianity. The recognition of Christianity as the official religion of the Byzantine Empire in $313 \mathrm{AD}$ did not mean that paganism had disappeared from Petra. In fact, most of the Nabataean temples in the city remained open until the second half of the $4^{\text {th }}$ century $\mathrm{AD}$, when the city was hit by the earthquake of 363 . It was this event that had the greatest impact on the abandoning of the city's temples, such as the Temple of the Winged Lions, the Temple of Qasr el-Bent and the Great Temple. The historical and archaeological evidence confirms the construction of a number of churches in Petra, which received considerable attention from the Christian clergy and the administration of the city during the $5^{\text {th }}$ and $6^{\text {th }}$ centuries $\mathrm{AD}$.
\end{abstract}

Keywords: Church, Christianity, paganism, Petra, Byzantine, religion, Southern Jordan.

Mohammed Al-Nasarat

Al-Hussein Bin Talal University

Department of History

Ma'an, P.O. Box (20)

Jordan 


\section{ILLUSTRATIONS}

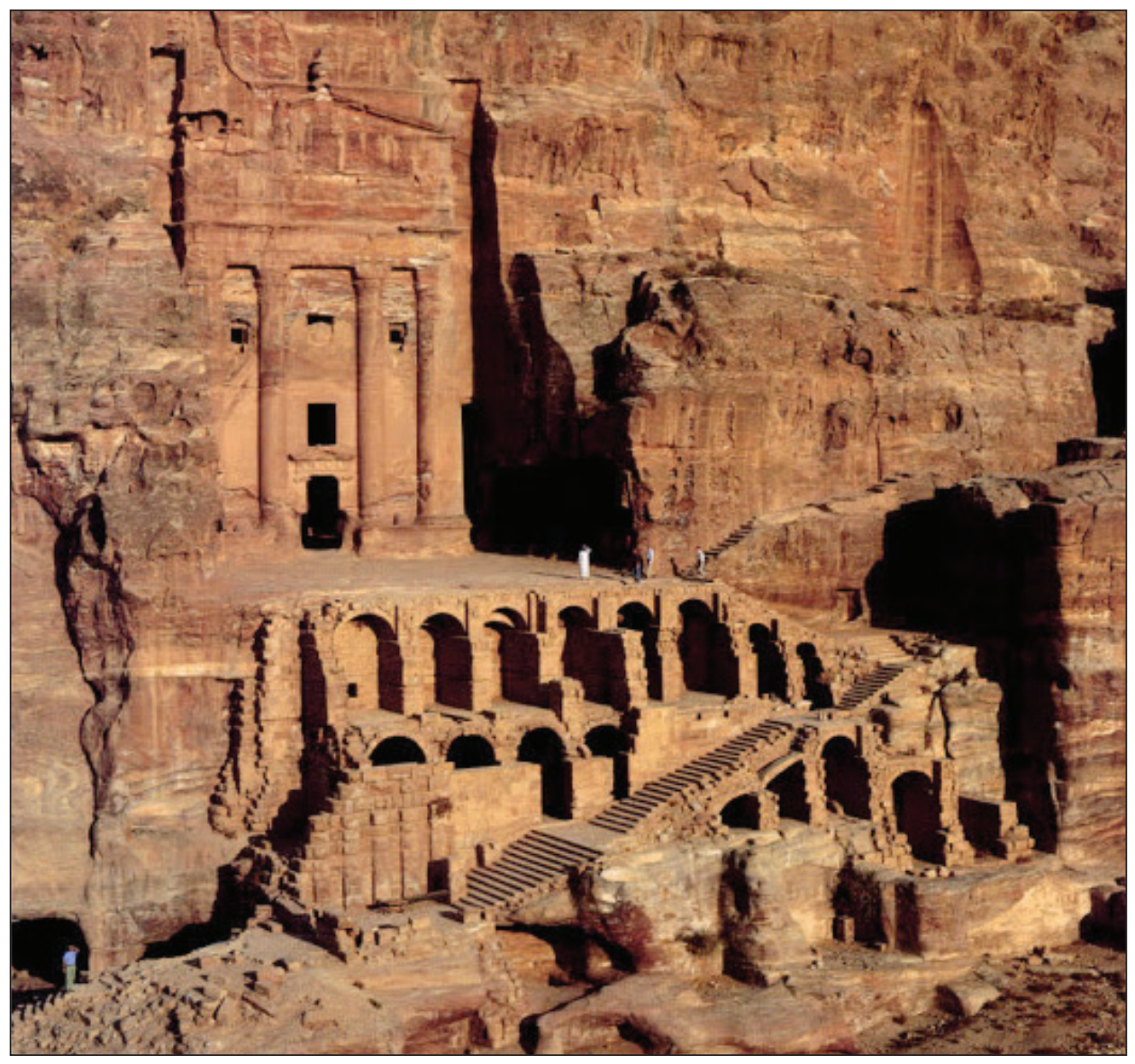

Fig. 1. The Urn Tomb, converted into a church by the Bishop Jason (J. TaYlor, Petra and the Lost Kingdom of the Nabataeans, Cambridge 2012, p. 205) 


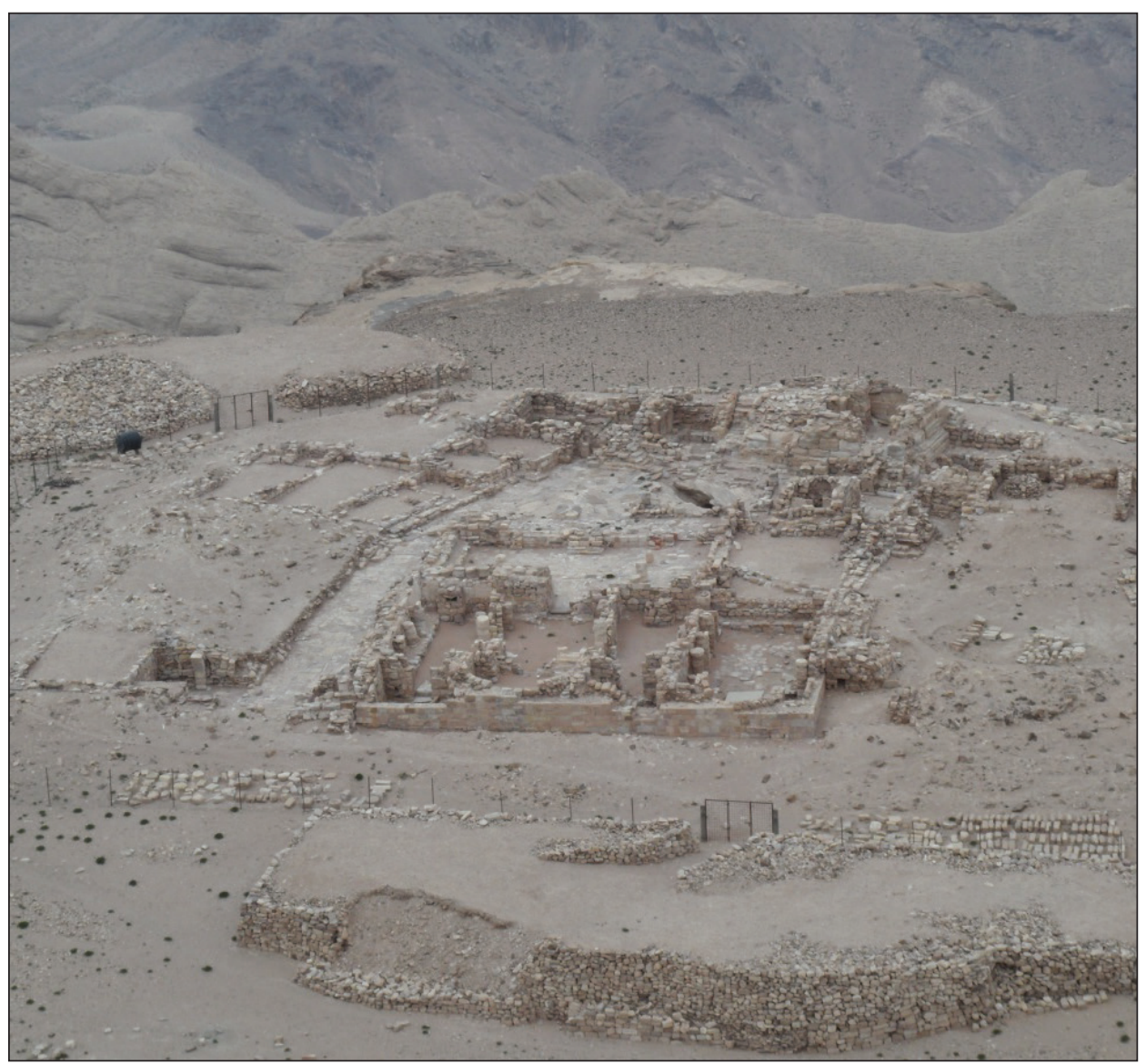

Fig. 2. Architectural complex on Jabal al-Nabī Hārūn (Photo by the author) 


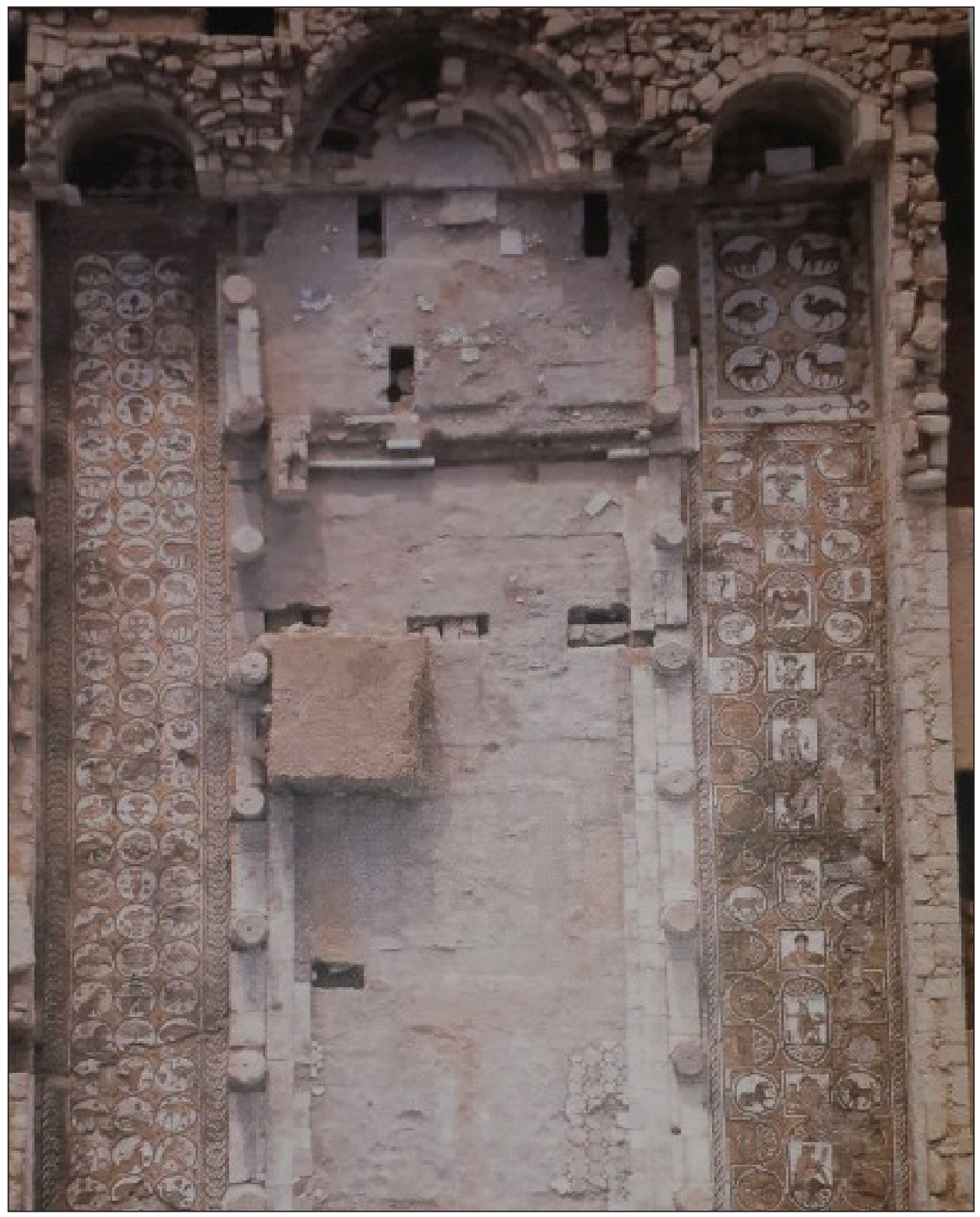

Fig. 3. The Main Petra Church (Z. Fiema, From the Annexation to Aaron. Petra in Roman and Byzantine Times, [in:] Petra. A City Forgotten and Rediscovered, ed. J. Frösen, Z. Fiema, Helsinki 2002, p. 70) 


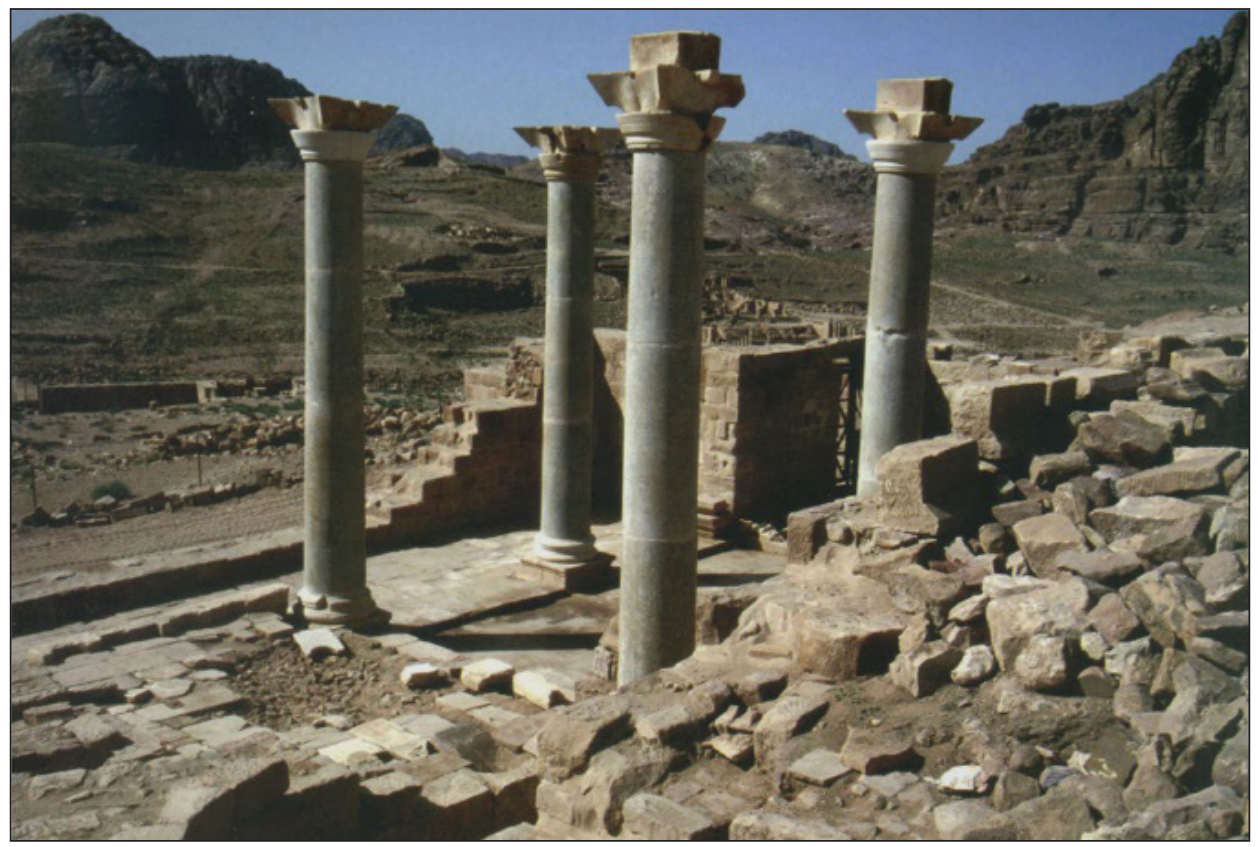

Fig. 4. View of the Blue Chapel with its four Egyptian blue granite columns with limestone capitals (P. BIKAI, The Churches of Byzantine Petra, "Near Eastern Archaeology" 65,2002, p. 275)

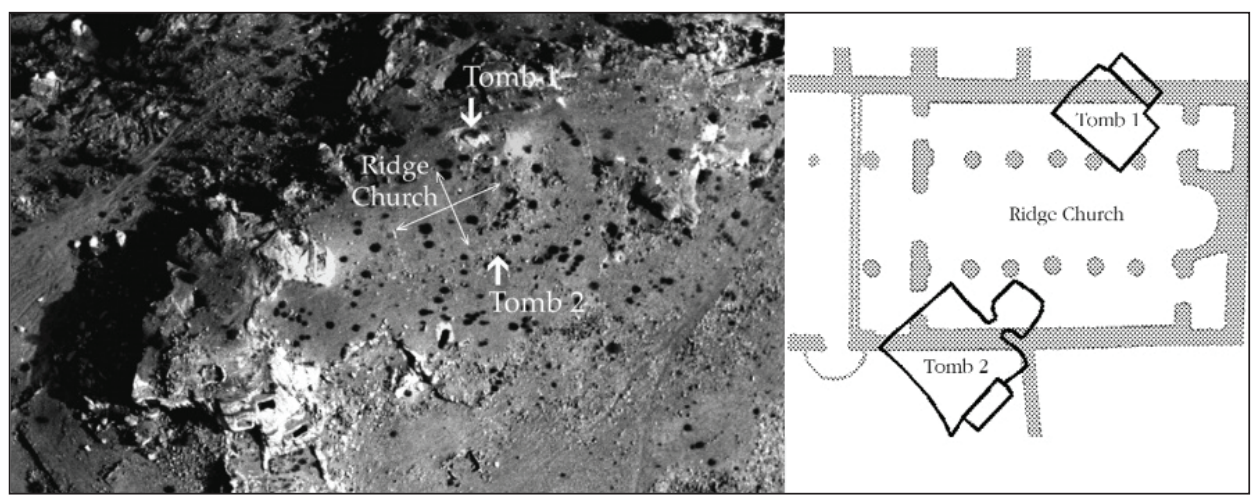

Fig. 5. Aerial view of the North Ridge Church, and Location of Nabataean Tombs 1 and 2 on the North Ridge (M. Perry, Life and Death in Nabataea. The North Ridge Tombs and Nabataean Burial Practices, "Near Eastern Archaeology" 65, 2002, p. 265-266) 